\title{
Proliferative Pathways of Vascular Smooth Muscle Cells in Response to Intermittent Hypoxia
}

\author{
Yoji Kyotani ${ }^{1, *}$, Shin Takasawa ${ }^{2}\left(\mathbb{D}\right.$ and Masanori Yoshizumi ${ }^{1}$ \\ 1 Department of Pharmacology, Nara Medical University School of Medicine, Kashihara 634-8521, Japan; \\ yoshizu@naramed-u.ac.jp \\ 2 Department of Biochemistry, Nara Medical University School of Medicine, Kashihara 634-8521, Japan; \\ shintksw@naramed-u.ac.jp \\ * Correspondence: cd147@naramed-u.ac.jp; Tel.: +81-744-29-8831
}

Received: 28 April 2019; Accepted: 30 May 2019; Published: 1 June 2019

\begin{abstract}
Obstructive sleep apnea (OSA) is characterized by intermittent hypoxia (IH) and is a risk factor for cardiovascular diseases (e.g., atherosclerosis) and chronic inflammatory diseases (CID). The excessive proliferation of vascular smooth muscle cells (VSMCs) plays a pivotal role in the progression of atherosclerosis. Hypoxia-inducible factor- 1 and nuclear factor- $\mathrm{kB}$ are thought to be the main factors involved in responses to IH and in regulating adaptations or inflammation pathways, however, further evidence is needed to demonstrate the underlying mechanisms of this process in VSMCs. Furthermore, few studies of IH have examined smooth muscle cell responses. Our previous studies demonstrated that increased interleukin (IL)-6, epidermal growth factor family ligands, and erbB2 receptor, some of which amplify inflammation and, consequently, induce CID, were induced by IH and were involved in the proliferation of VSMCs. Since IH increased IL-6 and epiregulin expression in VSMCs, the same phenomenon may also occur in other smooth muscle cells, and, consequently, may be related to the incidence or progression of several diseases. In the present review, we describe how IH can induce the excessive proliferation of VSMCs and we develop the suggestion that other CID may be related to the effects of IH on other smooth muscle cells.
\end{abstract}

Keywords: intermittent hypoxia; vascular smooth muscle cells; epiregulin; interleukin

\section{Introduction}

Obstructive sleep apnea (OSA) is characterized by repeated episodes of intermittent hypoxia $(\mathrm{IH})$, i.e., transient oxygen $\left(\mathrm{O}_{2}\right)$ desaturation, and resaturation. In clinical practice, OSA is commonly diagnosed by polysomnography and its severity is classified by the apnea hypopnea index (AHI) as follows: mild, $\mathrm{AHI} \geq 5$; moderate, $\mathrm{AHI} \geq 15$; severe, $\mathrm{AHI} \geq 30$ [1,2]. It is a highly prevalent disorder [3,4]; Peppard et al. estimated that the prevalence of moderate to severe sleep-disordered breathing is $10 \%$ and $3 \%$ among 30 - to 49 -year-old men and women, respectively, and $17 \%$ and $9 \%$ among 50 - to 70-year-old men and women, respectively [3]. Furthermore, OSA is well known as a risk factor for diabetes, systematic hypertension, and cardiovascular diseases [5-16], and also increases mortality from cardiovascular diseases (Figure 1) [17,18].

Continuous positive airway pressure (CPAP) is a clinically effective strategy for treating several diseases that derive from OSA. A number of studies have shown that CPAP decreases hemoglobin A1c levels, blood pressure, and inflammatory markers, as well as the frequency of cardiovascular events [19-22]. However, some studies have reported no significant effects of CPAP on glycemic control, serum lipids, hypertension, or cardiovascular events [23-26]. Additionally, patient compliance with CPAP treatment is often unsatisfactory [27-29]. Therefore, a clarification of the mechanisms underlying atherosclerosis in response to $\mathrm{IH}$ is important for establishing prophylaxis against OSA-related diseases. 


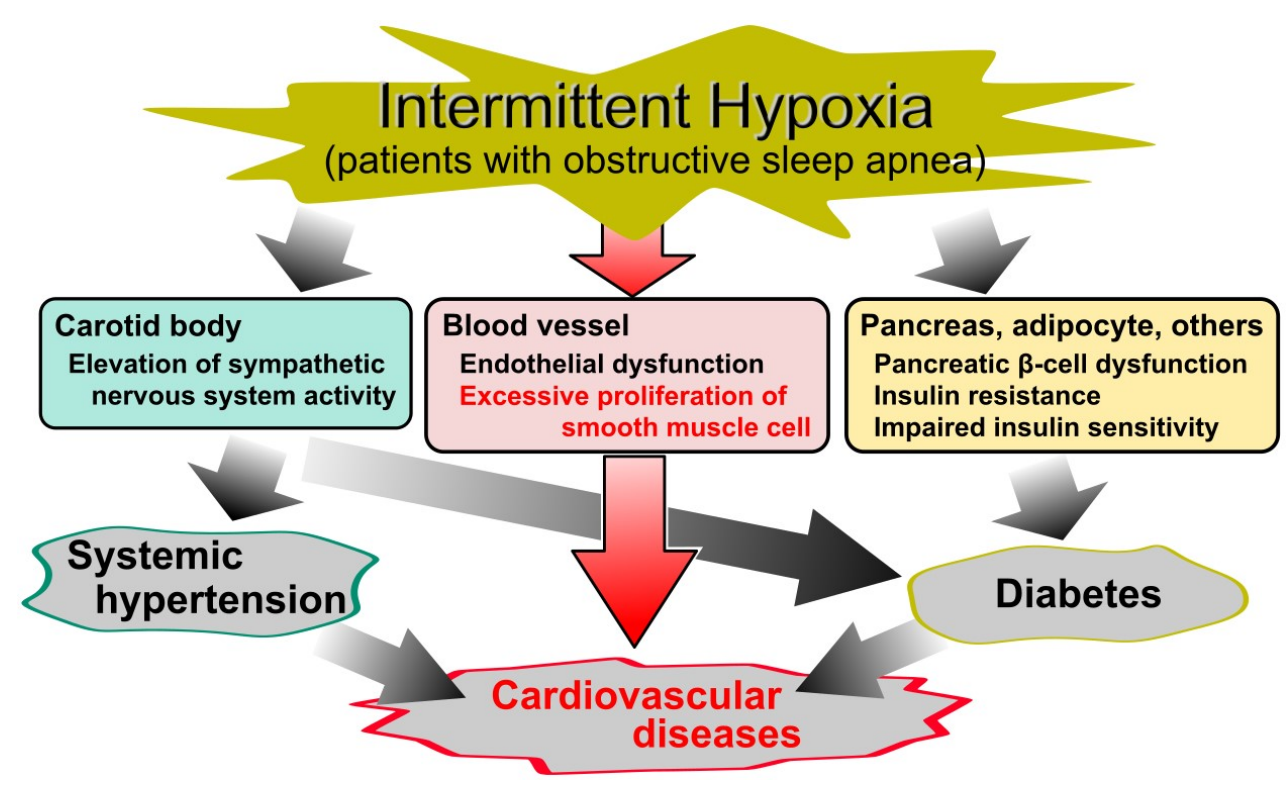

Figure 1. Cause and effect diagram of obstructive sleep apnea (OSA)-related diseases. Although intermittent hypoxia $(\mathrm{IH})$ in OSA is a known risk factor for diabetes, systematic hypertension, and cardiovascular diseases, the cellular mechanisms underlying the relationship between IH and cardiovascular diseases remain elusive. Despite a large number of studies of $\mathrm{IH}$, the molecular mechanism of IH on vascular smooth muscle cells is less established.

Atherosclerosis is well known as a major risk factor for cardiovascular diseases that can result in heart diseases and stroke. It is characterized by the formation of lesions, foam cells, and fibrous plaques. The major features in the progression of atherosclerosis are inflammation, the dysfunction of the endothelial barrier, oxidative stress, and the excessive proliferation of vascular smooth muscle cells (VSMCs) [30,31]. However, the pathophysiology of these cardiovascular diseases in OSA remains incompletely understood. OSA-related cardiovascular diseases are generally thought to be caused by various pathophysiological triggers, such as sympathetic nervous system overactivity, systemic inflammation, and oxidative stress, which in turn lead to metabolic dysregulation, hypertension, and endothelial dysfunction [32,33]. In vitro and in vivo models of IH have allowed researchers to investigate the influences of IH on several tissues and cells, and although articles on the vascular effects in IH and cardiovascular diseases in OSA syndrome have been previously published, the effects of IH on VSMCs, including its molecular mechanisms, have not been described [14,15]. Furthermore, there are few in vitro or in vivo studies of IH in other smooth muscle cells.

Recently, our laboratory demonstrated that IH directly increased the number of VSMCs by increasing the epidermal growth factor (EGF) family ligands and the EGF receptor erbB2, which were partially mediated by the IH-induced increase of interleukin (IL)-6 [34,35]. In the present review, we summarize the effects of IH on VSMCs, focusing on the intracellular mechanisms related to atherosclerosis, and develop a discussion of other chronic inflammatory diseases (CID).

\section{Vascular Smooth Muscle Cells (VSMCs) in Atherosclerosis}

Typically, VSMCs have been regarded as key players in the progression of atherosclerosis because their excessive proliferation promotes plaque formation, and then their presence in the advanced plaques prevent the rupture of the plaques' fibrous caps. VSMCs in normal arterial media have a spindle shape, termed the contractile phenotype, however, in damaged vessels, VSMCs develop a proinflammatory phenotype that produces proinflammatory mediators responsible for proliferation and chemotaxis. Thus, in both beneficial and detrimental ways, inflammatory responses and an excessive proliferation of VSMCs are responsible for the progression of atherosclerosis $[36,37]$. 


\section{Reactive Oxygen Species (ROS) and Transcriptional Factors in Intermittent Hypoxia (IH)}

A large number of previous in vivo and in vitro studies have shown that IH-induced intracellular mechanisms are mainly classified into two different transcription pathways, where the hypoxia-inducible factor (HIF)- 1 and the nuclear factor (NF)- $\mathrm{kB}$ play central roles [16,33,38]. In carotid bodies, IH-induced ROS generation is associated with HIF-1 activity and results in a sensory long-term facilitation of carotid bodies [39-41]. Several in vivo and in vitro studies have also observed that IH induces the activation of NF- $\mathrm{kB}$ in cardiovascular tissues and endothelial cells [42-45]. Our previous research, using reporter gene assays, also confirmed that IH induces the activation of NF- $\mathrm{KB}$ in cultured rat aortic smooth muscle cells (RASMCs) [34]. Taken together, all of these studies suggest that IH activates alternative transcriptional pathways depending on the tissue and cell types. Similarly, Kaczmarek et al. showed that IH decreased HIF-1 $\alpha$ expression in human dermal microvascular endothelial cells but increased HIF-1 $\alpha$ expression in human coronary artery endothelial cells, indicating that endothelial cells in cultures originating from distinct vascular beds respond differently to IH stress [46].

\subsection{Reactive Oxygen Species (ROS)}

ROS, such as superoxide anion, hydrogen peroxide, and hydroxyl radical, are well known as products of a partial reduction of oxygen. They are generated either in the processes of mitochondrial oxidative phosphorylation or during cellular responses to exogenous sources. Excessive ROS cause oxidative stress, which in turn results in macromolecular damage and is implicated in various diseases, including atherosclerosis [47]. In fact, it has been suggested that ROS are generated in patients with OSA [38,48-51] and are associated with the pathogenesis of cardiovascular diseases [52]. Furthermore, it has also been found that the mRNA molecules of heme oxygenase 1, superoxide dismutase (SOD) 1 and 2 , and catalase, which are all involved in the modulation of ROS, are also changed in patients with OSA [53].

Makarenko et al. conducted an in vitro study using human lung microvascular endothelial cells and found that $\mathrm{IH}$ increased ROS levels and led to the reorganization of cytoskeleton and junction proteins via the ROS-dependent activation of p38 mitogen-activated protein kinases (MAPK), which resulted in endothelial barrier dysfunction [54]. Similarly, Recoquillon et al. used human aortic endothelial cells and also reported that IH increased ROS and nitric oxide production, p65-NF- $\mathrm{KB}$ activation, and IL-6 secretion [44]. In contrast, Hoffmann et al. found that, in human coronary artery endothelial cells, IH increased manganese SOD activity via an increased dual-specificity phosphatase 1 (DUSP1) expression, and that overnight IH induced the expression of DUSP1 in mononuclear cells and granulocytes from patients with OSA [55]. Therefore, there is some evidence that ROS play a pivotal role in mediating the cardiovascular pathology associated with $\mathrm{IH}$.

However, Hayakawa et al. suggested that ROS were unlikely to mediate the activation of NF- $\mathrm{kB}$ [56], while Ryan et al. did not detect any influence on NF- $\mathrm{kB}$ activation from the presence of ROS scavenger N-acetyl-L-cysteine [43]. With respect to VSMCs, few studies have examined the involvement of ROS in IH. In our previous study, TEMPOL (1-oxyl-2,2,6,6-tetramethyl-4-hydroxypiperidine), a SOD mimic, did not exhibit any inhibitory effects on the IH-induced proliferation of RASMCs [34]. Therefore, further investigation is needed to elucidate the roles of ROS in VSMC responses in IH.

\subsection{Nuclear Factor (NF)- $\kappa B$}

The eukaryotic transcription factor, NF-kB, is a key mediator involved in the control of a large number of cellular processes, especially in immune and inflammatory responses $[57,58]$. In the NF- $\mathrm{KB}$ activation pathway, degradation of the inhibitor of NF- $\mathrm{KB}(\mathrm{I}-\mathrm{kB})$ results in the translocation of NF- $\mathrm{KB}$ to the nucleus. This in turn causes an increase of inflammatory cytokines, such as IL-6 and IL-8 [59,60]. 
A number of in vivo and in vitro studies have found that IH activates NF- $\mathrm{KB}$ in cardiovascular tissues and endothelial cells $[42,44,45]$. Ryan et al. demonstrated that IH activates NF- $\mathrm{KB}$, rather than HIF- $1 \alpha$, via p38 MAPK, in both HeLa cells and bovine aortic endothelial cells [43,61]. The well-known stress-activated protein kinase, p38 MAPK, is frequently activated by a wide range of environmental stresses and cytokines and induces inflammation [62]. Therefore, it seems likely that p38 MAPK is a key player in the IH-induced activation of NF- $\mathrm{KB}$ in cardiovascular tissues and endothelial cells. However, although the IH-induced activation of NF- $\mathrm{KB}$ has been observed in RASMCs [34], we did not find the phosphorylation of p38 MAPK in IH for $24 \mathrm{~h}$ [63]. We did, however, confirm the transient phosphorylation of extracellular signal-regulated kinase (ERK) $1 / 2$ and protein kinase B (Akt) induced by IH in RASMCs [63]. Imano et al. also found that IH increased the expression of ERK1/2 and NF- $\kappa B$ in human cardiac microvascular endothelial cells [45]. Taking into account the relationships among ERK1/2, Akt, HIF-1, and NF- KB [64-66], these factors, in addition to p38 MAPK, may also play important roles in the IH-induced activation of NF- $\mathrm{kB}$.

\subsection{Hypoxia-Inducible Factor (HIF)-1}

HIFs are well-characterized transcriptional factors that are one of primary regulators of oxygen homeostasis in every cell of the body. IH exposure creates an imbalance between the activities of HIF-1 and HIF-2 via ROS generation, which leads in turn to oxidative stress, resulting in pathological states like hypertension and breathing abnormalities [16,38]. It has been well established that IH induces the activation of HIF-1 in carotid bodies. However, few studies have shown any IH-induced activation of HIF-1 either in other tissues and cells or in vascular smooth muscles. Polotsky et al. suggested that, in human aortic endothelial cells, $\mathrm{IH}\left(16 \%\right.$ and $\left.0 \% \mathrm{O}_{2}\right)$ and sustained hypoxia $\left(4 \% \mathrm{O}_{2}\right)$ induced the mRNA expression of antioxidant genes, including heme oxygenase- 1 and nuclear factor (erythroid-derived 2)-like 2 (NRF2), excluding HIF-1-related genes, such as endothelin and glucose transporter (GLUT)1 [67]. Furthermore, Kaczmarek et al. demonstrated that IH-induced changes of HIF-1 $\alpha$ expression were quite different between endothelial cells in cultures originating from distinct vascular beds [46]. On the other hand, our study of RASMCs found that sustained hypoxia $\left(1 \% \mathrm{O}_{2}\right)$ induced a large increase of GLUT1 mRNA and IH which led to a very slight increase of GLUT1 mRNA [63]. Furthermore, IH has been shown to significantly increase IL-6 expression, which is mainly mediated by NF- $\mathrm{KB}$ rather than HIF-1 [35]. In conjunction with the studies showing the involvement of $\mathrm{NF}-\mathrm{KB}$ in IH, these results suggest that, in VSMCs, HIF-1 has more difficulty functioning in response to $\mathrm{IH}$, as compared with NF- $\mathrm{kB}$. Thus, NF- $\mathrm{kB}$, but not HIF-1, probably plays an important role in VSMC responses in $\mathrm{IH}$.

\subsection{Interaction Between Nuclear Factor (NF)- $\kappa B$ and Hypoxia-Inducible Factor (HIF)-1}

A significant relationship between NF- $\mathrm{KB}$ and HIF-1 has been established, along with their independent roles in hypoxia. The NF- $\mathrm{kB}$ binding site is located in the promoter region of the HIF-1 gene, and NF- $\kappa B$ regulates basal HIF- $1 \alpha$ expression $[68,69]$. I- $k B$ kinase- $\beta$ (IKK $\beta$ ), whose catalytic activity is repressed by $\mathrm{O}_{2}$-sensitive prolyl hydroxylases (PHDs), is a key factor in the mRNA expression of HIF-1 $\alpha[64,70]$. It has also been demonstrated that HIF-1 regulates NF- $\mathrm{KB}$ activity in human peripheral blood neutrophils, and that the overexpression of HIF-1 results in an increased NF- $\mathrm{kB}$ activity and an enhanced inflammatory response in HIF-1 transgenic mice [71,72]. Therefore, NF-KB and HIF-1 are thought to have interdependent roles and pathways that are important for modulating inflammatory responses to intermittent hypoxia (Figure 2) [73,74]. Furthermore, the susceptibility between NF-KB and HIF-1, depending on cells, may cause the different response to IH. 


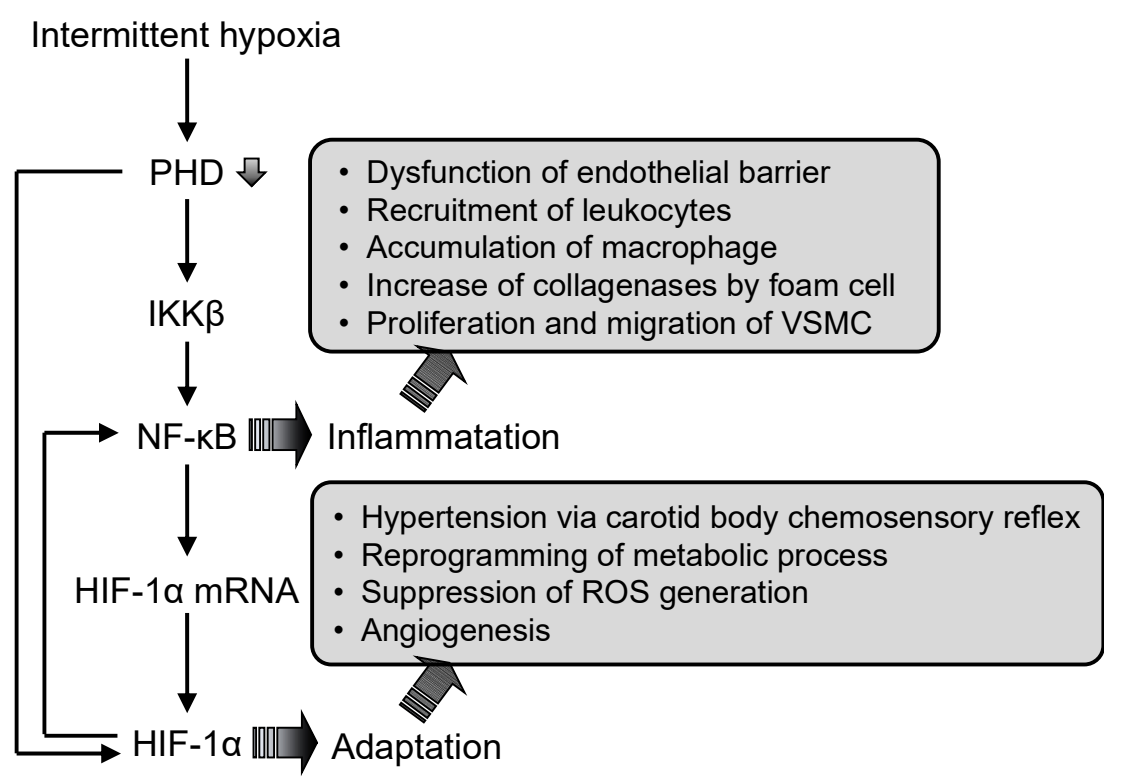

Figure 2. Model of the hypoxia-inducible factor (HIF)-1 and nuclear factor (NF)- $\mathrm{KB}$ activation mechanisms in response to intermittent hypoxia ( $\mathrm{IH})$. IH-induced hypoxic condition decreases PHD activity. As a result, NF- $\kappa B$ is induced to activate via the activation of I- $\kappa B$ kinase $\beta$ (IKK $\beta$ ), which activates both the NF- $\mathrm{KB}$ mediated inflammation pathway and the NF- $\mathrm{KB}$ mediated up-regulation of HIF-1. Activation of NF- $\mathrm{B}$ B and HIF-1 induces inflammation and adaptation to $\mathrm{IH}$, resulting in angiogenesis via the proliferation and migration of VSMC. PHD: prolyl hydroxylases.

\section{Interleukin (IL)-6}

Several clinical studies have demonstrated a significant correlation of OSA with inflammatory markers, such as C-reactive proteins, interleukins, intracellular adhesion molecules, and tumor necrosis factor- $\alpha$ [75-78]. These studies indicated that IH in patients with OSA induces systemic inflammation, which is involved in the progression of atherosclerosis. In fact, in a meta-analysis of 29 population-based prospective studies, IL-6 and IL-18 were associated with increases in the adjusted relative risks for nonfatal myocardial infarctions and coronary heart disease deaths [79].

Our in vitro model confirmed that IH increased IL-6 in human coronary artery smooth muscle cells (hCASMCs) [35]. Similarly, increases of IL-6 and IL-8 with IH have been observed in both human endothelial cells and cardiac myocytes $[44,67,80]$. These results suggest that IH causes inflammation in vessel walls or proximal tissues, since IL- 6 and IL-8 function as autocrine/paracrine inflammatory cytokines. The IL- 6 amplifier may also be present, due to the simultaneous activations of the nuclear factor NF- $\mathrm{kB}$ and the signal transducer and activator of transcription 3 (STAT3), which increases the expression of chemokines in non-immune cells and induces inflammation via a NF- $\mathrm{kB}$ loop, resulting in the accumulation of various immune cells and the dysregulation of homeostasis. The IL-6 amplifier is also thought to be associated with a number of diseases and disorders [81-83] as well as cardiovascular diseases, including atherosclerosis, in patients with OSA, since IH activates both NF-kB (via hypoxic conditions) and STAT3 (via increased IL-6) $[34,35,43,61,83]$.

In addition to inflammation, the creation of macrophage foam cells is also an important feature of the progression of atherosclerosis. Likely, IL-6 partially contributes to increases in major scavenger receptors such as scavenger receptor $\mathrm{A}$ and $\mathrm{CD} 36$, in macrophages, and likely induces macrophage foam cell formation [84]. Given the increases of IL-6 from VSMCs and other vascular tissues, IH may facilitate macrophage foam cell formations in lesions, and thereby contribute to the progression of atherosclerosis. 


\section{Epiregulin}

Epiregulin belongs to the EGF family and is expressed as type 1 transmembrane precursors, which are cleaved by disintegrin and metalloproteinase enzymes to release mature forms. The mature growth factors bind to members of the erbB family of receptor tyrosine kinases to regulate the proliferation, differentiation, and variation of mature cell functions. Epiregulin also plays an important role in angiogenesis and vascular remodeling, particularly during inflammation [85-87].

Takahashi et al. showed that epiregulin is released from ERK1/2- and p38 MAPK-activated VSMCs and it acts as a major autocrine/paracrine factor for VSMC dedifferentiation, and thus proliferation, suggesting that epiregulin regulates vascular remodeling such as atherosclerosis [88]. Similarly, our previous study found that IH induced the proliferation of VSMCs via an increase of epiregulin [34]. We confirmed that the phosphorylation level of ERK1/2 was significantly increased by IH and then became a decreased level as compared with that of normoxia in RASMCs, and that IH increased DUSP1 mRNA in RASMCs $[63,89]$. Hoffman et al. also reported an IH-induced increase of DUSP1 expression in human coronary artery endothelial cells [55]. Since DUSP1 is one of the mitogen-activated, stress-inducible and dual-specificity MAPK phosphatases [90], the imbalance between ERK1/2 and DUSP1 activities likely contributes to the IH-induced increase of epiregulin expression in VSMCs.

With respect to the IL- 6 amplifier, Murakami et al. demonstrated the involvement of epiregulin in the development of inflammatory diseases [91]. However, we found that IH up-regulated IL-6 which in turn increased epiregulin expression in hCASMCs [35]. These results suggest that IH-induced IL-6 and epiregulin cooperatively induce inflammation, resulting in the dysregulation of homeostasis in the vessel tissues of patients with OSA (Figure 3).

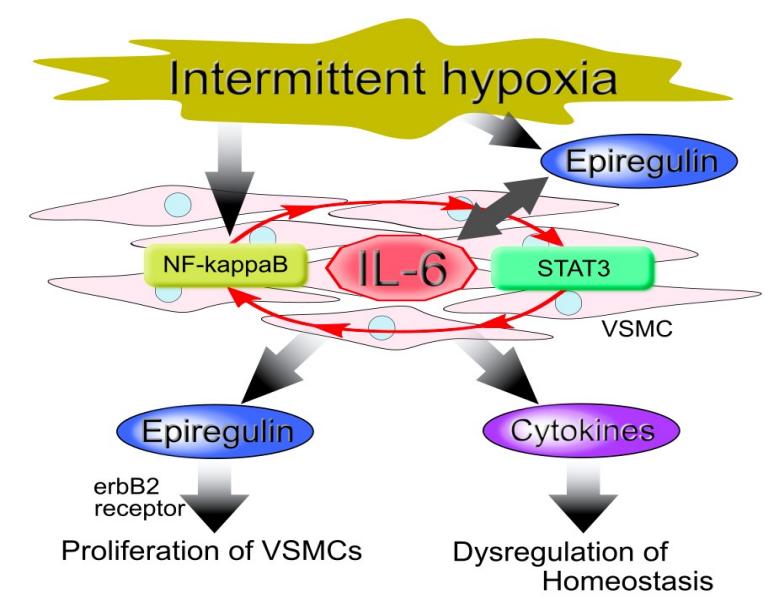

Figure 3. Model of vascular smooth muscle cell (VSMC) cellular responses to intermittent hypoxia (IH). IH induces the up-regulation of interleukin (IL)-6 via activation of the nuclear factor (NF) $k \mathrm{~B}$ and the signal transducer and activator of transcription 3 (STAT3), which involves the IL-6 amplifier (red arrow). This results in an increased expression of epiregulin and other cytokines that proliferate VSMCs, leading to atherosclerosis.

Interestingly, in our promoter assay using VSMCs, where an epiregulin promoter-luciferase reporter were transiently expressed, IH exhibited no significant effect on epiregulin promoter activity despite its up-regulation of epiregulin mRNA [35]. This suggests that the IH-induced increase of epiregulin mRNA does not depend on transcriptional activation, including any activation of NF- $\mathrm{KB}$ and HIF-1. Therefore, the underlying mechanisms in the IH-induced increase of epiregulin remain unclear and are very attractive areas for future research to establish prophylaxis for cardiovascular diseases in patients with OSA. Recently, there has been increased evidence that IH induces changes in microRNA expression in several types of cells in patients with sleep disorders [92-95], and therefore microRNAs may play pivotal roles in cellular responses to $\mathrm{IH}$, including the increase of epiregulin expression in VSMCs. 


\section{Chronic Inflammatory Diseases (CID)}

IL-6 and epiregulin are associated with a several CID, such as cancer, asthma and other pulmonary diseases, and Crohn's disease [85,96-99]. Furthermore, inflammation amplifiers, especially IL-6 and epiregulin, cause inflammation and consequently are associated with CID. IH increases the expression of IL-6 and epiregulin in VSMCs, and therefore may increase the incidence of CID in other tissues, as well as in vessel walls.

Martínez-García et al. attempted to analyze the relationship between OSA and cancer but found that the evidence was limited by a number of factors, including inadequately assessed $\mathrm{IH}$, nonspecific cancer sites, and the inclusion of studies designed to serve other purposes. They concluded that the evidence was not strong enough to infer a relationship between OSA and cancer incidence or progression [100]. In contrast, Gozal et al. reported that the presence of OSA may increase the risk of cancer incidence and worsen cancer prognoses [101]. However, the underlying molecular mechanisms of IH in cancer are not fully understood. IL-6 exhibits immune-suppressive effects on T cell-mediated anti-tumor immunity and is well known as a pivotal player in immunosuppressive states in tumor microenvironments, and in the development and metastasis of various cancers such as prostate and ovarian cancers [96,97,102-104]. Epiregulin, meanwhile, appears to contribute to the progression of several different human cancers, including bladder, stomach, colon, breast, and other cancers [85]. The IH-induced increases of IL-6 and epiregulin in VSMCs, therefore, let us speculate that IH also causes an increase of IL-6 and epiregulin, and consequently, chronic inflammation in other smooth muscle tissues, resulting in the progression of several cancers. This is consistent with the previously proposed paradigm that activation of inflammation amplifiers is associated with the development of various tumors [105].

IL-6 has been shown to play a pivotal role in the pathogenesis of lung diseases and to act as a key modulator of overall immune response, as well as non-immune cell responses [99]. The up-regulation of epiregulin has also been shown to increase IL-8 production, which contributes to the inflammation and tissue remodeling associated with asthma, bacterial pneumonia, and chronic obstructive pulmonary disease [85]. Given that IH increases IL-6 and epiregulin expression in VSMCs, the same phenomenon may occur in other smooth muscle cells, and thus could contribute to the pathogenesis or progression of diseases in the lungs and airways.

Crohn's disease is a CID that in $30 \%$ to $50 \%$ of patients is complicated by intestinal fibrosis and stricture formation as a result of dysregulated wound healing over time. Inflammation, cellular hyperplasia, and increased extracellular matrix production from smooth muscle cells are important factors in the development of fibrosis in patients with Crohn's disease [106]. Indeed, intestinal smooth muscle cells contribute to fibrosis via production of large amounts of extracellular matrix proteins, cytokines, and growth factors, including IL-6.

Taken together, these facts suggest the possibility that smooth muscle cells in each tissue play pivotal roles in several diseases, including cancer, asthma and other pulmonary diseases, and Crohn's disease. Therefore, in patients with OSA, IH could contribute to the progression of these diseases at a molecular level.

\section{Summary and Perspective}

OSA, which is characterized by $\mathrm{IH}$, is a highly prevalent respiratory disorder associated with morbidity and mortality from cardiovascular diseases. Atherosclerosis is a major chronic inflammatory cardiovascular disease that is characterized by an excessive proliferation and migration of VSMCs in lesions and plaques. Therefore, research into the intracellular mechanisms underlying IH in VSMCs can provide new insights that may help to establish effective preventive methods for cardiovascular diseases in patients with OSA.

Over the past decade, in vitro and in vivo models of IH have demonstrated intracellular responses to IH in several tissues and cells. In almost all in vitro studies, the effects of IH are compared with that in normoxia or SH. However, misgivings about the definition of hypoxia have recently arisen, because $21 \% \mathrm{O}_{2}$ as normoxia in the in vitro model of hypoxia represents hyperoxia. It is thought that few 
studies of $\mathrm{IH}$, including our previous studies, describe how to define normoxic and hypoxic conditions. For better investigation of $\mathrm{IH}$, it is important to confirm the normoxic and hypoxic conditions in cell culture media based on $\mathrm{PO} 2$ or $\mathrm{SpO}_{2}$ of blood in healthy human, patients with OSA and in vivo study as well as describing the setting of those conditions.

ROS and the transcriptional factors HIF-1 and NF- $\mathrm{KB}$ are commonly thought to regulate the inflammation and adaptation of tissues and cells in IH. However, the precise involvement of ROS and the predominant transcriptional factors in VSMCs due to IH have not yet been uncovered. We previously confirmed that IH induces the activation of NF-KB in RASMCs [34], but our promoter assay revealed that the transcriptional factors, such as NF-KB or HIF-1, may not be involved in the IH-induced increase of epiregulin mRNA. The mechanisms underlying IH-induced epiregulin increases thus require further investigation. However, did demonstrate that IH causes the proliferation of VSMCs, and that this is mediated by epiregulin, which in turn is up-regulated via IL-6 [34,35]. Given this, IL-6 amplifier, IL-6, and epiregulin may be key modulators of inflammation in vessels and other tissues in patients with OSA. Therefore, additional research is needed to establish the mechanisms that underly the responses of VSMCs and other smooth muscle cells to IH, and to yield novel therapeutic and prophylactic targets for CID, including cardiovascular diseases in patients with OSA.

Author Contributions: Conceptualization, Y.K. and S.T.; writing—original draft preparation, Y.K.; writing一review and editing, Y.K.; visualization, Y.K.; supervision, S.T.; project administration, M.Y.

Funding: This research received no external funding.

Acknowledgments: Our previous findings reported and discussed here were obtained thanks to members of Departments of Pharmacology and Biochemistry, Nara Medical University School of Medicine.

Conflicts of Interest: The authors declare no conflict of interest.

\section{Abbreviations}

$\begin{array}{ll}\text { Akt } & \text { Protein kinase B } \\ \text { CID } & \text { Chronic inflammatory diseases } \\ \text { CPAP } & \text { Continuous positive airway pressure } \\ \text { DUSP1 } & \text { Dual specificity protein phosphatase 1 } \\ \text { EGF } & \text { Epidermal growth factor } \\ \text { erbB } & \text { EGF receptor } \\ \text { ERK } & \text { Extracellular signal-regulated kinase } \\ \text { GLUT } & \text { Glucose transporter } \\ \text { hCASMC } & \text { Human coronary artery smooth muscle cell } \\ \text { HIF } & \text { Hypoxia-inducible factor } \\ \text { IH } & \text { Intermittent hypoxia } \\ \text { I-kB } & \text { Inhibitor of NF-kB } \\ \text { IKK } \beta & \text { I-kB kinase- } \beta \\ \text { IL } & \text { Interleukin } \\ \text { MAPK } & \text { Mitogen-activated protein kinase } \\ \text { NF- } k B & \text { Nucleus factor-kB } \\ \text { NRF2 } & \text { Nuclear factor (erythroid-derived 2)-like 2 } \\ \text { OSA } & \text { Obstructive sleep apnea } \\ \text { PHD } & \text { Prolyl hydroxylases } \\ \text { RASMC } & \text { Rat aortic smooth muscle cell } \\ \text { ROS } & \text { Reactive oxygen species } \\ \text { SOD } & \text { Superoxide dismutase } \\ \text { STAT3 } & \text { Signal transducer and activator of transcription 3 } \\ \text { VSMC } & \text { Vascular smooth muscle cell }\end{array}$




\section{References}

1. Kapur, V.K.; Auckley, D.H.; Chowdhuri, S.; Kuhlmann, D.C.; Mehra, R.; Ramar, K.; Harrod, C.G. Clinical Practice Guideline for Diagnostic Testing for Adult Obstructive Sleep Apnea: An American Academy of Sleep Medicine Clinical Practice Guideline. J. Clin. Sleep Med. 2017, 13, 479-504. [CrossRef] [PubMed]

2. Laratta, C.R.; Ayas, N.T.; Povitz, M.; Pendharkar, S.R. Diagnosis and treatment of obstructive sleep apnea in adults. CMAJ. 2017, 189, E1481-E1488. [CrossRef]

3. Peppard, P.E.; Young, T.; Barnet, J.H.; Palta, M.; Hagen, E.W.; Hla, K.M. Increased prevalence of sleep-disordered breathing in adults. Am. J. Epidemiol. 2013, 177, 1006-1014. [CrossRef]

4. Young, T.; Palta, M.; Dempsey, J.; Skatrud, J.; Weber, S.; Badr, S. The occurrence of sleep-disordered breathing among middle-aged adults. N. Engl. J. Med. 1993, 328, 1230-1235. [CrossRef] [PubMed]

5. Kent, B.D.; Grote, L.; Ryan, S.; Pépin, J.-L.; Bonsignore, M.R.; Tkacova, R.; Saaresranta, T.; Verbraecken, J.; Lévy, P.; Hedner, J.; et al. Diabetes mellitus prevalence and control in sleep-disordered breathing. Chest 2014, 146, 982-990. [CrossRef] [PubMed]

6. Wang, X.; Bi, Y.; Zhang, Q.; Pan, F. Obstructive sleep apnoea and the risk of Type 2 diabetes: A meta-analysis of prospective cohort studies: OSA and Type 2 diabetes. Respirology 2013, 18, 140-146. [CrossRef]

7. Sahlin, C.; Sandberg, O.; Gustafson, Y.; Bucht, G.; Carlberg, B.; Stenlund, H.; Franklin, K.A. Obstructive sleep apnea is a risk factor for death in patients with stroke: A 10-year follow-up. Arch. Intern. Med. 2008, 168, 297. [CrossRef]

8. Sorajja, D.; Gami, A.S.; Somers, V.K.; Behrenbeck, T.R.; Garcia-Touchard, A.; Lopez-Jimenez, F. Independent association between obstructive sleep apnea and subclinical coronary artery disease. Chest 2008, 133, 927-933. [CrossRef] [PubMed]

9. Durán, J.; Esnaola, S.; Rubio, R.; Iztueta, Á. Obstructive sleep apnea-hypopnea and related clinical features in a population-based sample of subjects aged 30 to 70 yr. Am. J. Respir. Crit. Care Med. 2001, 163, 685-689. [CrossRef] [PubMed]

10. Nieto, F.J. Association of sleep-disordered breathing, sleep apnea, and hypertension in a large community-based study. JAMA 2000, 283, 1829. [CrossRef] [PubMed]

11. Peppard, P.E. Longitudinal study of moderate weight change and sleep-disordered breathing. JAMA 2000, 284, 3015. [CrossRef] [PubMed]

12. Ryan, S. Adipose tissue inflammation by intermittent hypoxia: Mechanistic link between obstructive sleep apnoea and metabolic dysfunction. J. Physiol. 2017, 595, 2423-2430. [CrossRef]

13. Conde, S.V.; Sacramento, J.F.; Guarino, M.P.; Gonzalez, C.; Obeso, A.; Diogo, L.N.; Monteiro, E.C.; Ribeiro, M.J. Carotid body, insulin, and metabolic diseases: Unraveling the links. Front. Physiol. 2014, 5, 418. [CrossRef] [PubMed]

14. Garvey, J.F.; Taylor, C.T.; McNicholas, W.T. Cardiovascular disease in obstructive sleep apnoea syndrome: The role of intermittent hypoxia and inflammation. Eur. Respir. J. 2009, 33, 1195-1205. [CrossRef] [PubMed]

15. Kanagy, N.L. Vascular effects of intermittent hypoxia. ILAR J. 2009, 50, 282-288. [CrossRef]

16. Prabhakar, N.R.; Semenza, G.L. Adaptive and maladaptive cardiorespiratory responses to continuous and intermittent hypoxia mediated by hypoxia-inducible factors 1 and 2. Physiol. Rev. 2012, 92, 967-1003. [CrossRef]

17. Azarbarzin, A.; Sands, S.A.; Stone, K.L.; Taranto-Montemurro, L.; Messineo, L.; Terrill, P.I.; Ancoli-Israel, S.; Ensrud, K.; Purcell, S.; White, D.P.; et al. The hypoxic burden of sleep apnoea predicts cardiovascular disease-related mortality: The osteoporotic fractures in men study and the sleep heart health study. Eur. Heart J. 2019, 40, 1149-1157. [CrossRef]

18. Young, T.; Finn, L.; Peppard, P.E.; Szklo-Coxe, M.; Austin, D.; Nieto, F.J.; Stubbs, R.; Hla, K.M. Sleep disordered breathing and mortality: Eighteen-year follow-up of the Wisconsin sleep cohort. Sleep 2008, 31, 1071-1078.

19. Martínez-Cerón, E.; Barquiel, B.; Bezos, A.-M.; Casitas, R.; Galera, R.; García-Benito, C.; Hernanz, A.; Alonso-Fernández, A.; Garcia-Rio, F. Effect of continuous positive airway pressure on glycemic control in patients with obstructive sleep apnea and Type 2 diabetes. A randomized clinical trial. Am. J. Respir. Crit. Care Med. 2016, 194, 476-485. [CrossRef] 
20. Barbé, F.; Durán-Cantolla, J.; Capote, F.; de la Peña, M.; Chiner, E.; Masa, J.F.; Gonzalez, M.; Marín, J.M.; Garcia-Rio, F.; de Atauri, J.D.; et al. Long-term effect of continuous positive airway pressure in hypertensive patients with sleep apnea. Am. J. Respir. Crit. Care Med. 2010, 181, 718-726. [CrossRef]

21. Gottlieb, D.J.; Punjabi, N.M.; Mehra, R.; Patel, S.R.; Quan, S.F.; Babineau, D.C.; Tracy, R.P.; Rueschman, M.; Blumenthal, R.S.; Lewis, E.F.; et al. CPAP versus oxygen in obstructive sleep apnea. N. Engl. J. Med. 2014, 370, 2276-2285. [CrossRef] [PubMed]

22. Marin, J.M.; Carrizo, S.J.; Vicente, E.; Agusti, A.G. Long-term cardiovascular outcomes in men with obstructive sleep apnoea-hypopnoea with or without treatment with continuous positive airway pressure: An observational study. Lancet 2005, 365, 1046-1053. [CrossRef]

23. Yu, J.; Zhou, Z.; McEvoy, R.D.; Anderson, C.S.; Rodgers, A.; Perkovic, V.; Neal, B. Association of positive airway pressure with cardiovascular events and death in adults with sleep apnea: A systematic review and meta-analysis. JAMA 2017, 318, 156. [CrossRef] [PubMed]

24. Shaw, J.E.; Punjabi, N.M.; Naughton, M.T.; Willes, L.; Bergenstal, R.M.; Cistulli, P.A.; Fulcher, G.R.; Richards, G.N.; Zimmet, P.Z. The effect of treatment of obstructive sleep apnea on glycemic control in Type 2 diabetes. Am. J. Respir. Crit. Care Med. 2016, 194, 486-492. [CrossRef] [PubMed]

25. Myhill, P.C.; Davis, W.A.; Peters, K.E.; Chubb, S.A.P.; Hillman, D.; Davis, T.M.E. Effect of continuous positive airway pressure therapy on cardiovascular risk factors in patients with Type 2 diabetes and obstructive sleep apnea. J. Clin. Endocrinol. Metab. 2012, 97, 4212-4218. [CrossRef]

26. Barbé, F.; Durán-Cantolla, J.; Sánchez-de-la-Torre, M.; Martínez-Alonso, M.; Carmona, C.; Barceló, A.; Chiner, E.; Masa, J.F.; Gonzalez, M.; Marín, J.M.; et al. Effect of continuous positive airway pressure on the incidence of hypertension and cardiovascular events in nonsleepy patients with obstructive sleep apnea: A randomized controlled trial. JAMA 2012, 307, 2161-2168. [CrossRef]

27. Campos-Rodriguez, F.; Martinez-Alonso, M.; Sanchez-de-la-Torre, M.; Barbe, F. Long-term adherence to continuous positive airway pressure therapy in non-sleepy sleep apnea patients. Sleep Med. 2016, 17, 1-6. [CrossRef] [PubMed]

28. Hussain, S.F.; Irfan, M.; Waheed, Z.; Alam, N.; Mansoor, S.; Islam, M. Compliance with continuous positive airway pressure (CPAP) therapy for obstructive sleep apnea among privately paying patients- a cross sectional study. BMC Pulm. Med. 2014, 14, 188. [CrossRef]

29. Sawyer, A.M.; Gooneratne, N.S.; Marcus, C.L.; Ofer, D.; Richards, K.C.; Weaver, T.E. A systematic review of CPAP adherence across age groups: Clinical and empiric insights for developing CPAP adherence interventions. Sleep Med. Rev. 2011, 15, 343-356. [CrossRef]

30. Russell, R. Atherosclerosis-An inflammatory disease. N. Engl. J. Med. 1999, 340, 115-126.

31. Lusis, A.J. Atherosclerosis. Nature 2000, 407, 233-241. [CrossRef] [PubMed]

32. Levy, P.; Ryan, S.; Oldenburg, O.; Parati, G. Sleep apnoea and the heart. Eur. Respir. Rev. 2013, 22, 333-352. [CrossRef]

33. Ryan, S.; Taylor, C.T.; McNicholas, W.T. Systemic inflammation: A key factor in the pathogenesis of cardiovascular complications in obstructive sleep apnoea syndrome? Postgrad. Med. J. 2009, 85, 693-698. [CrossRef] [PubMed]

34. Kyotani, Y.; Ota, H.; Itaya-Hironaka, A.; Yamauchi, A.; Sakuramoto-Tsuchida, S.; Zhao, J.; Ozawa, K.; Nagayama, K.; Ito, S.; Takasawa, S.; et al. Intermittent hypoxia induces the proliferation of rat vascular smooth muscle cell with the increases in epidermal growth factor family and ErbB2 receptor. Exp. Cell Res. 2013, 319, 3042-3050. [CrossRef] [PubMed]

35. Kyotani, Y.; Itaya-Hironaka, A.; Yamauchi, A.; Sakuramoto-Tsuchida, S.; Makino, M.; Takasawa, S.; Yoshizumi, M. Intermittent hypoxia-induced epiregulin expression by IL-6 production in human coronary artery smooth muscle cells. FEBS Open Bio. 2018, 8, 868-876. [CrossRef]

36. Chistiakov, D.A.; Orekhov, A.N.; Bobryshev, Y.V. Vascular smooth muscle cell in atherosclerosis. Acta Physiol. 2015, 214, 33-50. [CrossRef] [PubMed]

37. Bennett, M.R.; Sinha, S.; Owens, G.K. Vascular smooth muscle cells in atherosclerosis. Circ. Res. 2016, 118, 692-702. [CrossRef]

38. Semenza, G.L.; Prabhakar, N.R. The role of hypoxia-inducible factors in carotid body (patho) physiology: HIF and the carotid body. J. Physiol. 2018, 596, 2977-2983. [CrossRef] 
39. Peng, Y.-J.; Nanduri, J.; Yuan, G.; Wang, N.; Deneris, E.; Pendyala, S.; Natarajan, V.; Kumar, G.K.; Prabhakar, N.R. NADPH oxidase is required for the sensory plasticity of the carotid body by chronic intermittent hypoxia. J. Neurosci. 2009, 29, 4903-4910. [CrossRef]

40. Peng, Y.-J.; Overholt, J.L.; Kline, D.; Kumar, G.K.; Prabhakar, N.R. Induction of sensory long-term facilitation in the carotid body by intermittent hypoxia: Implications for recurrent apneas. Proc. Natl. Acad. Sci. 2003, 100, 10073-10078. [CrossRef]

41. Peng, Y.-J.; Yuan, G.; Ramakrishnan, D.; Sharma, S.D.; Bosch-Marce, M.; Kumar, G.K.; Semenza, G.L.; Prabhakar, N.R. Heterozygous HIF-1 $\alpha$ deficiency impairs carotid body-mediated systemic responses and reactive oxygen species generation in mice exposed to intermittent hypoxia: HIF-1 and intermittent hypoxia. J. Physiol. 2006, 577, 705-716. [CrossRef] [PubMed]

42. Greenberg, H.; Ye, X.; Wilson, D.; Htoo, A.K.; Hendersen, T.; Liu, S.F. Chronic intermittent hypoxia activates nuclear factor-кB in cardiovascular tissues in vivo. Biochem. Biophys. Res. Commun. 2006, 343, 591-596. [CrossRef] [PubMed]

43. Ryan, S.; McNicholas, W.T.; Taylor, C.T. A critical role for p38 map kinase in NF-kB signaling during intermittent hypoxia/reoxygenation. Biochem. Biophys. Res. Commun. 2007, 355, 728-733. [CrossRef] [PubMed]

44. Recoquillon, S.; Gómez-Guzmán, M.; Rodier, M.; Koffi, C.; Nitiéma, M.; Gagnadoux, F.; Martínez, M.C.; Andriantsitohaina, R. Non-muscular myosin light chain kinase triggers intermittent hypoxia-induced interleukin-6 release, endothelial dysfunction and permeability. Sci. Rep. 2017, 7, 13664. [CrossRef]

45. Imano, H.; Kato, R.; Tanikawa, S.; Yoshimura, F.; Nomura, A.; Ijiri, Y.; Yamaguchi, T.; Izumi, Y.; Yoshiyama, M.; Hayashi, T. Factor Xa inhibition by rivaroxaban attenuates cardiac remodeling due to intermittent hypoxia. J. Pharmacol. Sci. 2018, 137, 274-282. [CrossRef] [PubMed]

46. Kaczmarek, E.; Bakker, J.P.; Clarke, D.N.; Csizmadia, E.; Kocher, O.; Veves, A.; Tecilazich, F.; O'Donnell, C.P.; Ferran, C.; Malhotra, A. Molecular biomarkers of vascular dysfunction in obstructive sleep apnea. PLoS ONE 2013, 8, e70559. [CrossRef] [PubMed]

47. Ray, P.D.; Huang, B.-W.; Tsuji, Y. Reactive oxygen species (ROS) homeostasis and redox regulation in cellular signaling. Cell. Signal. 2012, 24, 981-990. [CrossRef]

48. Prabhakar, N.R.; Peng, Y.-J.; Yuan, G.; Nanduri, J. Reactive oxygen radicals and gaseous transmitters in carotid body activation by intermittent hypoxia. Cell Tissue Res. 2018, 372, 427-431. [CrossRef]

49. Semenza, G.L.; Prabhakar, N.R. Neural regulation of hypoxia-inducible factors and redox state drives the pathogenesis of hypertension in a rodent model of sleep apnea. J. Appl. Physiol. 2015, 119, 1152-1156. [CrossRef]

50. Dyugovskaya, L.; Lavie, P.; Lavie, L. Increased adhesion molecules expression and production of reactive oxygen species in leukocytes of sleep apnea patients. Am. J. Respir. Crit. Care Med. 2002, 165, 934-939. [CrossRef]

51. Schulz, R.; Mahmoudi, S.; Hattar, K.; Sibelius, U.; Olschewski, H.; Mayer, K.; Seeger, W.; Grimminger, F. Enhanced release of superoxide from polymorphonuclear neutrophils in obstructive sleep apnea: Impact of continuous positive airway pressure therapy. Am. J. Respir. Crit. Care Med. 2000, 162, 566-570. [CrossRef] [PubMed]

52. Kattoor, A.J.; Pothineni, N.V.K.; Palagiri, D.; Mehta, J.L. Oxidative stress in atherosclerosis. Curr. Atheroscler. Rep. 2017, 19, 42. [CrossRef] [PubMed]

53. Hoffmann, M.S.; Singh, P.; Wolk, R.; Romero-Corral, A.; Raghavakaimal, S.; Somers, V.K. Microarray studies of genomic oxidative stress and cell cycle responses in obstructive sleep apnea. Antioxid. Redox Signal. 2007, 9, 661-669. [CrossRef] [PubMed]

54. Makarenko, V.V.; Usatyuk, P.V.; Yuan, G.; Lee, M.M.; Nanduri, J.; Natarajan, V.; Kumar, G.K.; Prabhakar, N.R. Intermittent hypoxia-induced endothelial barrier dysfunction requires ROS-dependent MAP kinase activation. Am. J. Physiol.-Cell Physiol. 2014, 306, C745-C752. [CrossRef] [PubMed]

55. Hoffmann, M.S.; Singh, P.; Wolk, R.; Narkiewicz, K.; Somers, V.K. Obstructive sleep apnea and intermittent hypoxia increase expression of dual specificity phosphatase 1. Atherosclerosis 2013, 231, 378-383. [CrossRef] [PubMed]

56. Hayakawa, M. Evidence that reactive oxygen species do not mediate NF-kB activation. EMBO J. 2003, 22, 3356-3366. [CrossRef]

57. Hayden, M.S.; Ghosh, S. Shared principles in NF-кB signaling. Cell 2008, 132, 344-362. [CrossRef] 
58. Li, Q.; Verma, I.M. NF-кB regulation in the immune system. Nat. Rev. Immunol. 2002, 2, 725-734. [CrossRef]

59. Son, Y.-H.; Jeong, Y.-T.; Lee, K.-A.; Choi, K.-H.; Kim, S.-M.; Rhim, B.-Y.; Kim, K. Roles of MAPK and NF-kB in interleukin-6 induction by lipopolysaccharide in vascular smooth muscle cells. J. Cardiovasc. Pharmacol. 2008, 51, 71-77. [CrossRef]

60. Kunsch, C.; Rosen, C.A. NF-kappa B subunit-specific regulation of the interleukin-8 promoter. Mol. Cell. Biol. 1993, 13, 6137-6146. [CrossRef]

61. Ryan, S.; Taylor, C.T.; McNicholas, W.T. Selective activation of inflammatory pathways by intermittent hypoxia in obstructive sleep apnea syndrome. Circulation 2005, 112, 2660-2667. [CrossRef] [PubMed]

62. Coulthard, L.R.; White, D.E.; Jones, D.L.; McDermott, M.F.; Burchill, S.A. p38 $8^{\mathrm{MAPK}}$ : Stress responses from molecular mechanisms to therapeutics. Trends Mol. Med. 2009, 15, 369-379. [CrossRef] [PubMed]

63. Kyotani, Y.; Ota, H.; Itaya-Hironaka, A.; Yamauchi, A.; Sakuramoto-Tsuchida, S.; Zhao, J.; Nagayama, K.; Ozawa, K.; Takasawa, S.; Kimura, H.; et al. Sleep apnea syndrome as an emerging risk factor for type 2 diabetes and atherosclerosis: Evidence and underlying mechanism. In Proceedings of the 9th Metabolic Syndrome, Type 2 Diabetes and Atherosclerosis Congress (MSDA 2014), Kyoto, Japan, 12-14 September 2014.

64. Rius, J.; Guma, M.; Schachtrup, C.; Akassoglou, K.; Zinkernagel, A.S.; Nizet, V.; Johnson, R.S.; Haddad, G.G.; Karin, M. NF-kB links innate immunity to the hypoxic response through transcriptional regulation of HIF-1 $\alpha$. Nature 2008, 453, 807-811. [CrossRef] [PubMed]

65. Madrid, L.V.; Mayo, M.W.; Reuther, J.Y.; Baldwin, A.S. Akt stimulates the transactivation potential of the RelA/p65 subunit of NF- $\mathrm{kB}$ through utilization of the IкB kinase and activation of the mitogen-activated protein kinase p38. J. Biol. Chem. 2001, 276, 18934-18940. [CrossRef]

66. Minet, E.; Arnould, T.; Michel, G.; Roland, I.; Mottet, D.; Raes, M.; Remacle, J.; Michiels, C. ERK activation upon hypoxia: Involvement in HIF-1 activation. FEBS Lett. 2000, 468, 53-58. [CrossRef]

67. Polotsky, V.Y.; Savransky, V.; Bevans-Fonti, S.; Reinke, C.; Li, J.; Grigoryev, D.N.; Shimoda, L.A. Intermittent and sustained hypoxia induce a similar gene expression profile in human aortic endothelial cells. Physiol. Genomics 2010, 41, 306-314. [CrossRef] [PubMed]

68. BelAiba, R.S.; Bonello, S.; Zähringer, C.; Schmidt, S.; Hess, J.; Kietzmann, T.; Görlach, A. Hypoxia up-regulates hypoxia-inducible factor- $1 \alpha$ transcription by involving phosphatidylinositol 3-kinase and nuclear factor $\mathrm{kB}$ in pulmonary artery smooth muscle cells. Mol. Biol. Cell 2007, 18, 4691-4697. [CrossRef] [PubMed]

69. Van Uden, P.; Kenneth, N.S.; Rocha, S. Regulation of hypoxia-inducible factor- $1 \alpha$ by NF-кB. Biochem. J. 2008, 412, 477-484. [CrossRef]

70. Cummins, E.P.; Berra, E.; Comerford, K.M.; Ginouves, A.; Fitzgerald, K.T.; Seeballuck, F.; Godson, C.; Nielsen, J.E.; Moynagh, P.; Pouyssegur, J.; et al. Prolyl hydroxylase-1 negatively regulates IkB kinase- $\beta$, giving insight into hypoxia-induced NFkB activity. Proc. Natl. Acad. Sci. USA 2006, 103, 18154-18159. [CrossRef] [PubMed]

71. Walmsley, S.R.; Print, C.; Farahi, N.; Peyssonnaux, C.; Johnson, R.S.; Cramer, T.; Sobolewski, A.; Condliffe, A.M.; Cowburn, A.S.; Johnson, N.; et al. Hypoxia-induced neutrophil survival is mediated by HIF-1 $\alpha$-dependent NF-кB activity. J. Exp. Med. 2005, 201, 105-115. [CrossRef]

72. Scortegagna, M.; Cataisson, C.; Martin, R.J.; Hicklin, D.J.; Schreiber, R.D.; Yuspa, S.H.; Arbeit, J.M. HIF-1 regulates epithelial inflammation by cell autonomous $\mathrm{NF} \kappa \mathrm{B}$ activation and paracrine stromal remodeling. Blood 2008, 111, 3343-3354. [CrossRef] [PubMed]

73. Taylor, C.T. Interdependent roles for hypoxia inducible factor and nuclear factor- $\mathrm{B}$ in hypoxic inflammation. J. Physiol. 2008, 586, 4055-4059. [CrossRef] [PubMed]

74. Eltzschig, H.K.; Carmeliet, P. Hypoxia and inflammation. N. Engl. J. Med. 2011, 364, 656-665. [CrossRef] [PubMed]

75. Nadeem, R.; Molnar, J.; Madbouly, E.M.; Nida, M.; Aggarwal, S.; Sajid, H.; Naseem, J.; Loomba, R. Serum inflammatory markers in obstructive sleep apnea: A meta-analysis. J. Clin. Sleep Med. 2013, 9, 1003-1012. [CrossRef]

76. Wang, J.; Yu, W.; Gao, M.; Zhang, F.; Gu, C.; Yu, Y.; Wei, Y. Impact of obstructive sleep apnea syndrome on endothelial function, arterial stiffening, and serum inflammatory markers: An updated meta-analysis and metaregression of 18 studies. J. Am. Heart Assoc. 2015, 4, e002454. [CrossRef] [PubMed]

77. Ciccone, M.; Scicchitano, P.; Zito, A.; Cortese, F.; Boninfante, B.; Falcone, V.; Quaranta, V.; Ventura, V.; Zucano, A.; Di Serio, F.; et al. Correlation between inflammatory markers of atherosclerosis and carotid intima-media thickness in obstructive sleep apnea. Molecules 2014, 19, 1651-1662. [CrossRef] [PubMed] 
78. Minoguchi, K.; Yokoe, T.; Tazaki, T.; Minoguchi, H.; Tanaka, A.; Oda, N.; Okada, S.; Ohta, S.; Naito, H.; Adachi, M. Increased carotid intima-media thickness and serum inflammatory markers in obstructive sleep apnea. Am. J. Respir. Crit. Care Med. 2005, 172, 625-630. [CrossRef]

79. Kaptoge, S.; Seshasai, S.R.K.; Gao, P.; Freitag, D.F.; Butterworth, A.S.; Borglykke, A.; Di Angelantonio, E.; Gudnason, V.; Rumley, A.; Lowe, G.D.O.; et al. Inflammatory cytokines and risk of coronary heart disease: New prospective study and updated meta-analysis. Eur. Heart J. 2014, 35, 578-589. [CrossRef] [PubMed]

80. Wu, J.; Stefaniak, J.; Hafner, C.; Schramel, J.P.; Kaun, C.; Wojta, J.; Ullrich, R.; Tretter, V.E.; Markstaller, K.; Klein, K.U. Intermittent hypoxia causes inflammation and injury to human adult cardiac myocytes. Anesth. Analg. 2016, 122, 373-380. [CrossRef]

81. Ogura, H.; Murakami, M.; Okuyama, Y.; Tsuruoka, M.; Kitabayashi, C.; Kanamoto, M.; Nishihara, M.; Iwakura, Y.; Hirano, T. Interleukin-17 promotes autoimmunity by triggering a positive-feedback loop via interleukin-6 induction. Immunity 2008, 29, 628-636. [CrossRef]

82. Murakami, M.; Okuyama, Y.; Ogura, H.; Asano, S.; Arima, Y.; Tsuruoka, M.; Harada, M.; Kanamoto, M.; Sawa, Y.; Iwakura, Y.; et al. Local microbleeding facilitates IL-6- and IL-17-dependent arthritis in the absence of tissue antigen recognition by activated T cells. J. Exp. Med. 2011, 208, 103-114. [CrossRef] [PubMed]

83. Lee, J.; Nakagiri, T.; Kamimura, D.; Harada, M.; Oto, T.; Susaki, Y.; Shintani, Y.; Inoue, M.; Miyoshi, S.; Morii, E.; et al. IL-6 amplifier activation in epithelial regions of bronchi after allogeneic lung transplantation. Int. Immunol. 2013, 25, 319-332. [CrossRef]

84. Takeda, N.; Manabe, I.; Shindo, T.; Iwata, H.; Iimuro, S.; Kagechika, H.; Shudo, K.; Nagai, R. Synthetic retinoid Am80 reduces scavenger receptor expression and atherosclerosis in mice by inhibiting IL-6. Arterioscler. Thromb. Vasc. Biol. 2006, 26, 1177-1183. [CrossRef] [PubMed]

85. Riese, D.J.; Cullum, R.L. Epiregulin: Roles in normal physiology and cancer. Semin. Cell Dev. Biol. 2014, 28, 49-56. [CrossRef]

86. Singh, B.; Carpenter, G.; Coffey, R.J. EGF receptor ligands: Recent advances. F1000Research 2016, 5, 2270. [CrossRef] [PubMed]

87. Dreux, A.C.; Lamb, D.J.; Modjtahedi, H.; Ferns, G.A.A. The epidermal growth factor receptors and their family of ligands: Their putative role in atherogenesis. Atherosclerosis 2006, 186, 38-53. [CrossRef]

88. Takahashi, M.; Hayashi, K.; Yoshida, K.; Ohkawa, Y.; Komurasaki, T.; Kitabatake, A.; Ogawa, A.; Nishida, W.; Yano, M.; Monden, M.; et al. Epiregulin as a major autocrine/paracrine factor released from ERK- and p38MAPK-activated vascular smooth muscle cells. Circulation 2003, 108, 2524-2529. [CrossRef] [PubMed]

89. Kyotani, Y.; Zhao, J.; Itaya-Hironaka, A.; Yamauchi, A.; Sakuramoto-Tsuchida, S.; Makino, M.; Takasawa, S.; Yoshizumi, M. Intermittent hypoxia-induced cell proliferation via ipregulations of interleukin- 6 and epiregulin. In Proceedings of the 18th World Congress of Basic and Clinical Pharmacology (WCP2018), Kyoto, Japan, 1-6 July 2018.

90. Caunt, C.J.; Keyse, S.M. Dual-specificity MAP kinase phosphatases (MKPs): Shaping the outcome of MAP kinase signalling. FEBS J. 2013, 280, 489-504. [CrossRef]

91. Murakami, M.; Harada, M.; Kamimura, D.; Ogura, H.; Okuyama, Y.; Kumai, N.; Okuyama, A.; Singh, R.; Jiang, J.-J.; Atsumi, T.; et al. Disease-association analysis of an inflammation-related feedback loop. Cell Rep. 2013, 3, 946-959. [CrossRef] [PubMed]

92. Lacedonia, D.; Scioscia, G.; Palladino, G.P.; Gallo, C.; Carpagnano, G.E.; Sabato, R.; Barbaro, M.P.F. MicroRNA expression profile during different conditions of hypoxia. Oncotarget 2018, 9, 35114-35122. [CrossRef]

93. Liu, K.-X.; Chen, Q.; Chen, G.-P.; Huang, J.-C.; Huang, J.-F.; He, X.-R.; Lin, T.; Lin, Q.-C. Inhibition of MicroRNA-218 reduces HIF-1 $\alpha$ by targeting on Robo1 in mice aortic endothelial cells under intermittent hypoxia. Oncotarget 2017, 8, 104359-104366. [PubMed]

94. Uchiyama, T.; Ota, H.; Itaya-Hironaka, A.; Shobatake, R.; Yamauchi, A.; Sakuramoto-Tsuchida, S.; Makino, M.; Kimura, H.; Takeda, M.; Ohbayashi, C.; et al. Up-regulation of Selenoprotein P and HIP/PAP mRNAs in hepatocytes by intermittent hypoxia via down-regulation of miR-203. Biochem. Biophys. Rep. 2017, 11, 130-137. [CrossRef] [PubMed]

95. Uchiyama, T.; Itaya-Hironaka, A.; Yamauchi, A.; Makino, M.; Sakuramoto-Tsuchida, S.; Shobatake, R.; Ota, H.; Takeda, M.; Ohbayashi, C.; Takasawa, S. Intermittent hypoxia up-regulates CCL2, RETN, and TNF $\alpha$ mRNAs in adipocytes via down-regulation of miR-452. Int. J. Mol. Sci. 2019, 20, 1960. [CrossRef]

96. Browning, L.; Patel, M.R.; Horvath, E.B.; Tawara, K.; Jorcyk, C.L. IL-6 and ovarian cancer: Inflammatory cytokines in promotion of metastasis. Cancer Manag. Res. 2018, 10, 6685-6693. [CrossRef] 
97. Nguyen, D.P.; Li, J.; Tewari, A.K. Inflammation and prostate cancer: The role of interleukin 6 (IL-6). BJU Int . 2014, 113, 986-992. [CrossRef] [PubMed]

98. Maggio, M.; Guralnik, J.M.; Longo, D.L.; Ferrucci, L. Interleukin-6 in aging and chronic disease: A magnificent pathway. J. Gerontol. A. Biol. Sci. Med. Sci. 2006, 61, 575-584. [CrossRef] [PubMed]

99. Rincon, M.; Irvin, C.G. Role of IL-6 in asthma and other inflammatory pulmonary diseases. Int. J. Biol. Sci. 2012, 8, 1281-1290. [CrossRef] [PubMed]

100. Martínez-García, M.Á.; Campos-Rodriguez, F.; Barbé, F. Cancer and OSA: Current evidence from human studies. Chest 2016, 150, 451-463. [CrossRef]

101. Gozal, D.; Farré, R.; Nieto, F.J. Obstructive sleep apnea and cancer: Epidemiologic links and theoretical biological constructs. Sleep Med. Rev. 2016, 27, 43-55. [CrossRef]

102. Kitamura, H.; Ohno, Y.; Toyoshima, Y.; Ohtake, J.; Homma, S.; Kawamura, H.; Takahashi, N.; Taketomi, A. Interleukin-6/STAT3 signaling as a promising target to improve the efficacy of cancer immunotherapy. Cancer Sci. 2017, 108, 1947-1952. [CrossRef]

103. Kumari, N.; Dwarakanath, B.S.; Das, A.; Bhatt, A.N. Role of interleukin-6 in cancer progression and therapeutic resistance. Tumor Biol. 2016, 37, 11553-11572. [CrossRef] [PubMed]

104. Tsukamoto, H.; Fujieda, K.; Senju, S.; Ikeda, T.; Oshiumi, H.; Nishimura, Y. Immune-suppressive effects of interleukin-6 on T-cell-mediated anti-tumor immunity. Cancer Sci. 2018, 109, 523-530. [CrossRef] [PubMed]

105. Atsumi, T.; Singh, R.; Sabharwal, L.; Bando, H.; Meng, J.; Arima, Y.; Yamada, M.; Harada, M.; Jiang, J.-J.; Kamimura, D.; et al. Inflammation amplifier, a new paradigm in cancer biology. Cancer Res. 2014, 74, 8-14. [CrossRef]

106. Li, C.; Kuemmerle, J.F. Mechanisms that mediate the development of fibrosis in patients with Crohn's disease. Inflamm. Bowel Dis. 2014, 20, 1250-1258. [CrossRef] [PubMed]

(C) 2019 by the authors. Licensee MDPI, Basel, Switzerland. This article is an open access article distributed under the terms and conditions of the Creative Commons Attribution (CC BY) license (http://creativecommons.org/licenses/by/4.0/). 